\title{
Phylogenetic analysis of spring virema of carp virus reveals distinct subgroups with common origins for recent isolates in North America and the UK
}

\author{
O. Miller ${ }^{1,2, *}$, F. J. Fuller ${ }^{1}$, W. A. Gebreyes ${ }^{1}$, G. A. Lewbart ${ }^{3}$, I. S. Shchelkunov ${ }^{4}$, \\ R. B. Shivappa ${ }^{1}$, C. Joiner ${ }^{5}$, G. Woolford ${ }^{5}$, D. M. Stone ${ }^{5}$, P. F. Dixon ${ }^{5}$, M. E. Raley ${ }^{1}$, \\ J. F. Levine ${ }^{1}$ \\ ${ }^{1}$ Department of Population Health and Pathobiology, College of Veterinary Medicine, North Carolina State University, \\ 4700 Hillsborough St. Raleigh, North Carolina 27606, USA \\ ${ }^{2}$ United States Department of Agriculture, Animal Plant and Health Inspection Service, Veterinary Services, \\ 920 Campus Drive, Raleigh, North Carolina 27606, USA \\ ${ }^{3}$ Department of Clinical Sciences, College of Veterinary Medicine, North Carolina State University, \\ 4700 Hillsborough St., Raleigh, North Carolina 27606, USA \\ ${ }^{4}$ All-Russia Research Institute of Freshwater Fisheries, Rybnoe, Dmitrov Region, Moscow Province 141821, Russia \\ ${ }^{5}$ The Centre for Environment, Fisheries, and Aquaculture Science (CEFAS), Weymouth, Dorset DT4 8UB, UK
}

\begin{abstract}
Genetic relationships between 35 spring viremia of carp virus (SVCV) genogroup Ia isolates were determined based on the nucleotide sequences of the phosphoprotein (P) gene and glycoprotein (G) genes. Phylogenetic analysis based on P gene sequences revealed 2 distinct subgroups within SVCV genogroup Ia, designated SVCV Iai and Iaii, and suggests at least 2 independent introductions of the virus into the USA in 2002. Combined P- and G-sequence data support the emergence of SVCV in Illinois, USA, and in Lake Ontario, Canada, from the initial outbreak in Wisconsin, USA, and demonstrate a close genetic link to viruses isolated during routine import checks on fish brought into the UK from Asia. The data also showed a genetic link between SVCV isolations made in Missouri and Washington, USA, in 2004 and the earlier isolation made in North Carolina, USA, in 2002. However, based on the close relationship to a 2004 UK isolate, the data suggest than the Washington isolate represents a third introduction into the US from a common source, rather than a reemergence from the 2002 isolate. There was strong phylogenetic support for an Asian origin for 9 of 16 UK viruses isolated either from imported fish, or shown to have been in direct contact with fish imported from Asia. In one case, there was $100 \%$ nucleotide identity in the G-gene with a virus isolated in China.
\end{abstract}

KEY WORDS: Spring viremia of carp · SVCV · Phosphoprotein gene · Glycoprotein gene · Phylogenetic analysis · Molecular epidemiology

\section{INTRODUCTION}

Spring viremia of carp virus (SVCV) or Rhabdovirus carpio, has been isolated during outbreaks of disease in more than 30 countries, including the USA (Fijan et al. 1971, World Organization for Animal Health [OIE] available at: www.oie.int/fdc/eng/en_fdc.htm). Spring viremia of carp disease (SVC) is endemic in parts of continental Europe, Russia, and states of the former
USSR. Estimates in Europe alone suggest annual losses attributable to SVC of around $4000 \mathrm{t}$ (Fijan 1999, Zhang 2002). Mortality in young carp can be as high as $70 \%$, and the severity of the disease is reflected in its inclusion on the OIE list of notifiable viral diseases of finfish (Wolf 1988, Ahne et al. 2002).

Phylogenetic analysis of 36 partial G gene sequences of SVCV and the related pike fry rhabdovirus (PFRV) identified 4 distinct genogroups (Stone et al. 2003). All 
of the SVCV isolates formed a genetic cluster and were assigned to a single genogroup (genogroup I) that could be further sub-divided based on both phylogenetic and geographic origin of the isolates examined (Ia to Id). Asian isolates were classified within group Ia. Moldovan, Ukrainian and Russian isolates were assigned to genogroups Ib and Ic, while isolates presumably from the UK and other European countries were classified in genogroup Id. Other SVCV genes also offer discriminatory potential. Using the SVCV N gene as a target, Shchelkunov et al. (2005) developed a restriction fragment length polymorphism (RFLP) assay that distinguished 2 major and several intermediate minor genogroups among more than 20 European SVCV isolates, and a clear geographic correlation was found for some of the genogroups.

The first isolation of a group Ia SVC virus was made in 1997 from a mirror carp Cyprinus carpio carpio, followed in 1998 by isolations from asymptomatic koi carp Cyprinus carpio koi and goldfish Carassius auratus during routine import checks of ornamental fish imported into the UK from China (People's Republic of China). An SVC virus was isolated in the previous year from common carp held at the wholesaler's site, with fish originating from the same source. Based on partial glycoprotein gene sequence, this isolate was also assigned to Genogroup Ia (Stone et al. 2003).

A comprehensive surveillance program was undertaken by China for exit-entry and quarantine during 1998 to 2002, with no evidence of SVCV. However, following the association of Genogroup Ia viruses with the SVC outbreaks in North Carolina, USA (Goodwin 2002), and Wisconsin, USA (Dikkeboom et al. 2004), the authorities adopted a stricter SVCV surveillance program throughout China during 2003. During this more stringent testing, 2 strains of SVCV were isolated separately from koi carp (isolate 890) and common carp (isolate 992) in the Tianjin region of northern China in 2003 (Liu et al. 2004). Since these initial findings, a number of SVCV isolations have been made in both the USA and the UK, and for the latter there is supporting documentation in most cases to link the virus isolation with fish imported directly from China or to facilities holding fish recently imported from China.

In the USA, there have been 5 case reports of isolation of SVCV in cyprinids during the spring season (OIE website available at: www.collabcen.net/toWeb/ aq2.asp). Four of these were associated with disease outbreaks occurring in koi and goldfish breeder farms in the states of Virginia (VA) and North Carolina (NC) (reported-July 2002), in feral carp in a public lake (Cedar Lake, Wisconsin [WI] August 2002), in a backyard pond of koi and goldfish (Washington [WA], June 2004), and in koi breeder farms (Missouri [MO], July
2004). The fifth isolate originated from a non-clinical case in feral carp sampled during a routine surveillance (Cal Slag Illinois Channel, Illinois [ILL], summer 2003) (available at: www.fws.gov/news/NewsReleases/ showNews.cfm?newsId=E5DE11CB-EF51-49E8-A147 A9955185C7C9).

Tracebacks conducted by the Animal and Plant Health Inspection Service (APHIS) of the commercial breeder farms in NC and MO and the backyard pond owner who bought fish from a pet store, indicated that each of these outbreaks followed the introductions of fish imported from an Asian production facility of unknown SVC-status, or imported from Asian countries known to have SVC (Federal Register 2006). More recently, SVCV was isolated from wild common carp in Hamilton Harbor, Lake Ontario in an open water production system (September 2006) (OIE World Animal Health Information available at: www.oie.int/wahidprod/public.php?page=disease_immediate_summary\& selected_year=2006) following a routine export screening for viral hemorrhagic septicemia virus (VHSV) prior to export to France (B. Souters pers. comm.). All 6 of these case reports were determined to be in SVCV group Ia, based on partial G gene sequences.

In the UK, a further isolation of SVCV was made in 1998 from tench Tinca tinca held at a site that had recently received fish from China. In 2001, SVCV was isolated from koi carp in a hobbyist's pond, and from koi carp taken from a mixed stock of fish originating from China and Japan and kept at the supplier's site. Similarly, in 2002, SVCV was isolated from koi carp and golden orf Leuciscus idus in a hobbyist's pond. Although in this case no SVCV positive fish were identified on the supplier's site, the supplier and a fish retail site shown to be positive in the same year had a common wholesaler who regularly received fish from China.

In 2004, SVC was isolated from consignments of goldfish, koi carp and common carp imported from Italy. The virus was isolated in the same year from goldfish in a mixed stock of fish including carp received from China.

In 2005, isolations were made from goldfish and common carp but in both cases there was no supporting documentation to suggest a possible source of the infection.

During the period 2002 to 2004 numerous SVCV sequences were submitted to Genbank/EMBL by Y. Jiang of the Chinese Exit-entry and Quarantine Bureau (Liu et al. 2005, Teng et al. 2007).

Molecular epidemiology has become an important tool in disease surveillance and investigations of outbreaks, due to its ability to trace and identify possible infection sources (Ostroff 1999). The SVCV genome comprises 11019 nucleotides (nt) of negative sense 
single-stranded RNA that encodes 5 major proteins in the order 3'N (nucleoprotein) -P (phosphoprotein) -M (matrix) -G (glycoprotein) -L (polymerase) 5' (Bjorklund et al. 1996, Hoffmann et al. 2002). Studies conducted to date have largely focused on analysis of the glycoprotein $(\mathrm{G})$ gene for characterization of SVCV (Johnson et al. 1999, Oreshkova et al. 1999, Johansson et al. 2001, Ahne et al. 2002, Koutna et al. 2003, Stone et al. 2003, Liu et al. 2004, Dikkeboom et al. 2004).

The P gene of SVCV is 930 nt long, extends from positions 1407 to 2336 with respect to the genome, and encodes a protein of 309 amino acids (aa). The phosphoprotein P (formerly NS) is a component of the rhabdovirus nucleocapsid that, in association with $\mathrm{L}$ and $\mathrm{N}$ proteins, is required for transcription and replication, whereas the $\mathrm{G}$ and $\mathrm{M}$ proteins are not essential for these functions (Emerson \& Yu 1975, Roy 1981, Banerjee 1987, Oreshkova et al. 1999, Ahne et al. 2002, Shchelkunov et al. 2005).

While the $\mathrm{N}$ gene is highly conserved, there is a higher degree of variation in the P gene. $G$ and $P$ gene nucleotide differences between base pairs (bp) of European and Asian sequences of SVCV were 7.52 and $10.54 \%$, while their amino acid differences were 4.52 and $9.70 \%$, respectively (D. Stone unpubl. data). The phosphoprotein is also the least conserved among Lyssavirus genes and among the genes of VHSV strains (Johansson et al. 2002). Therefore, analysis of the $\mathrm{P}$ gene may be a more sensitive indicator of genetic diversity than either the $\mathrm{G}$ or $\mathrm{N}$ genes of SVCV, providing a more useful molecular epidemiological tool. In this study, we explored for the first time the use of the nucleotide sequence information of the SVCV phosphoprotein $\mathrm{P}$ gene for phylogenetic and epidemiological analysis. We combined the analysis of partial $G$ gene and $P$ gene sequences to establish the genetic relationship among the entire available group Ia SVCV isolates from North America and UK and those viruses isolated in China.

\section{MATERIALS AND METHODS}

This publication is the combined work of 2 laboratories, each using their own 'in house' methods to generate sequence data. Where methods differ, details of both protocols have been provided.

Viruses and cell lines. The US (American) SVCV isolates were obtained from A. Goodwin, University of Arkansas at Pine Bluff; K. Snekvik and J. Thompson, Washington Animal Diagnostic Disease Laboratory, and J. Warg, US Department of Agriculture (APHIS) National Veterinary Services Laboratory, Ames, Iowa. The Canadian SVCV isolate was obtained from B. Souter, Department of Fisheries and Oceans, Mani- toba, and the remaining viruses were obtained from the OIE SVC Reference Laboratory, The Centre for Environment, Fisheries, and Aquaculture Science (CEFAS), Weymouth UK (Table 1). Reference viruses used to determine specificity of primers were: S30 (Genogroup I), pike fry rhabdovirus (PFRV) F4 (Genogroup III), and tench rhabdovirus (TenRV) 9946631.1, 950237 and 84-4 (Genogroup IV).

Epithelioma papulosum cyprini (EPC) cells were used for propagation of the US SVC viruses, except for isolate PB02-131 for which bluegill Lepomis macrochirus fry cells (BF-2) were used. The cells were grown in monolayer cultures in L-15 Leibovitz RS medium with $5 \%$ fetal bovine serum, infected with American SVCV isolates at a multiplicity of infection of 0.1 and incubated at $20^{\circ} \mathrm{C}$ until $80 \%$ cytopathic effect was observed. Lyophilized international SVCV and other reference isolates were reconstituted in $0.5 \mathrm{ml} \mathrm{L-15}$ Leibovitz medium for direct viral RNA extraction and P gene amplification.

Virus clarification and RNA extraction. Culture fluid from infected cell cultures was harvested and cell debris removed by centrifugation at $4000 \times g$ for $5 \mathrm{~min}$ at room temperature. Viral RNA was extracted from $140 \mu \mathrm{l}$ of the supernatant using the QIAamp ${ }^{\circledR}$ Viral RNA Mini kit (Qiagen) according to manufacturer's protocol. Alternatively, RNA was extracted from $100 \mu \mathrm{l}$ of the supernatant using Trizol Reagent ${ }^{\mathrm{TM}}$ (Invitrogen) according to the method of Strommen \& Stone (1997).

Primer design. Specific oligonucleotide primers were designed to amplify the entire coding region of the $\mathrm{P}$ gene from genomic viral RNA. Conserved primer annealing sites were identified by alignment of published nucleotide sequences of the phosphoproteins of SVCV (GenBank accession nos. AY424883-AY424888, Hoffman et al. 2005). Consensus primers were designed using Vector NTI Advance 10 DNA and protein analysis software (VectorNTI, Invitrogen) to amplify the P gene of the European strains. The DNA sequence of the P gene of the Asian strain 980528 was used to manually design primers to amplify the $\mathrm{P}$ gene from Asian strains. Specific oligonucelotide primer pairs designed to amplify P gene from Asian SVCV isolates were designated Asian primers, and those that amplified the P gene of the European SVCV isolates were designated European primers (Table 2).

Reverse transcription and PCR amplification. In most cases the complete P-gene sequence was amplified according to the protocol in the One Step RT-PCR Kit (Qiagen) using primer sets SVCVPAF/ SVCVPAR and SVCVPF/ SVCVPR (Table 2). This was repeated independently at least twice for each virus isolate in order to obtain sequence information that was not subject to PCR bias. The reaction mix for RT-PCR consisted of $3 \mu \mathrm{l}$ of viral RNA and $47 \mu \mathrm{l}$ of the master mix 
Table 1. Rhabdovirus carpio. Isolates of SVCV and P gene sequence data analyzed. Publication details are given in parentheses; other sequence data are unpublished. ND: no data

\begin{tabular}{|c|c|c|c|c|c|c|}
\hline \multirow[t]{2}{*}{ Isolate } & \multirow{2}{*}{$\begin{array}{l}\text { Date of } \\
\text { Isolation }\end{array}$} & \multirow{2}{*}{$\begin{array}{l}\text { Country } \\
\text { Isolation }\end{array}$} & \multirow[t]{2}{*}{ Host species } & \multicolumn{2}{|c|}{ GenBank accession no. } & \multirow{2}{*}{$\begin{array}{l}\text { P gene } \\
\text { subgroup }\end{array}$} \\
\hline & & & & P gene & G gene & \\
\hline 970469 & 1997 & $\mathrm{UK}^{\mathrm{a}}$ & Common carp & DQ916049 & AJ538067 & Iai \\
\hline 980528 & 1998 & $\mathrm{UK}^{\mathrm{b}}$ & Goldfish & DQ916050 & AJ538066 & Iai \\
\hline 980451 & 1998 & $\mathrm{UK}^{\mathrm{a}}$ & Koi carp & ND & AJ538065 & Iai \\
\hline 980548 & 1998 & $\mathrm{UK}^{\mathrm{c}}$ & Tench & DQ916052 & $\mathrm{ND}$ & Iai \\
\hline 980619 & 1998 & $\mathrm{UK}^{\mathrm{b}}$ & Ghost carp & DQ916051 & AM501515 & Iai \\
\hline D-148 & 2001 & $\mathrm{UK}^{\mathrm{d}}$ & Common carp & DQ916055 & AM501513 & Iai \\
\hline D-120 & 2001 & $\mathrm{UK}^{\mathrm{d}}$ & Koi carp & DQ916056 & AM501514 & Iai \\
\hline PB02-46 (212364) & 2002 & $\mathrm{NC}, \mathrm{USA}$ & Koi carp & DQ904366 & DQ227501 (Warg et al. 2007) & Iaii \\
\hline PB02-131 (207194) & 2002 & WI, USA & Common carp & DQ904368 & DQ227500 (Warg et al. 2007) & Iai \\
\hline E208 & 2002 & UK & Koi carp, Golden orf & ND & AM501516 & Iaii \\
\hline E232 & 2002 & UK & Koi carp & ND & AM501512 & Iai \\
\hline 266921 & 2003 & IL, USA & Common carp & DQ904369 & DQ227502 (Warg et al. 2007) & Iai \\
\hline PB04-1664 (322383) & 2004 & MO, USA & Koi carp & DQ904370 & DQ22227504 (Warg et al. 2007) & Iaii \\
\hline 04-5061 (316715) & 2004 & WA, USA ${ }^{c}$ & Goldfish & DQ90436 & DQ227503 (Warg et al. 2007) & Iaii \\
\hline GO67 & 2004 & $\mathrm{UK}^{\mathrm{a}}$ & Goldfish & DQ916053 & AM501522 & Iai \\
\hline G083 & 2004 & $\mathrm{UK}^{\mathrm{e}}$ & Goldfish & DQ916048 & AM501521 & Iaii \\
\hline G108 & 2004 & $\mathrm{UK}^{\mathrm{e}}$ & Goldfish & DQ916047 & AM501520 & Iaii \\
\hline G144 1.2 & 2004 & $\mathrm{UK}^{\mathrm{e}}$ & Goldfish & ND & AM501527 & Iaii \\
\hline G144 2.8 & 2004 & $\mathrm{UK}^{\mathrm{e}}$ & Goldfish & ND & AM501523 & Iaii \\
\hline G144 3.1 & 2004 & $\mathrm{UK}^{\mathrm{e}}$ & Koi carp & ND & AM501519 & Iai \\
\hline G144 4.1 & 2004 & $\mathrm{UK}^{\mathrm{e}}$ & Koi carp & ND & AM501518 & Iai \\
\hline G144 5.2 & 2004 & $\mathrm{UK}^{\mathrm{e}}$ & Common carp & ND & AM501517 & Iai \\
\hline $\mathrm{H} 243$ & 2005 & UK & Common carp & DQ916054 & AM501511 & Iai \\
\hline H264 & 2005 & UK & Goldfish & ND & AM501510 & Iai \\
\hline HHOCarp06 & 2006 & Canada & Common carp & EF216718 & EF194065 & Iai \\
\hline S30 & 1969 & Yugoslavia & Common carp & DQ916041 & AJ538061 (Stone et al. 2003) & \\
\hline N3-14 & 1986 & Ukraine & Grass carp & ND & AJ538062 (Stone et al. 2003) & \\
\hline 880163 & 1988 & UK & Common carp & DQ916043 & EU003618 (Stone et al. 2003) & \\
\hline 940626 & 1994 & UK & Tench & DQ916044 & EU003617 (Stone et al. 2003) & \\
\hline P4 & 1983 & Russia & Common carp & EF417826 & AJ538074 (Stone et al. 2003) & \\
\hline N1-5 & 1986 & Ukraine & Bighead carp & AM501526 & AJ538064 (Stone et al. 2003) & \\
\hline RHV & 1989 & Ukraine & Rainbow trout & AM501525 & AJ538075 (Stone et al. 2003) & \\
\hline $2 / 90$ & 1990 & Moldova & Common carp & AM501524 & AJ538060 (Stone et al. 2003) & \\
\hline 01-01V1592 & 1999 & Germany & Koi carp & AY424883 (Hoffman et al. 2005) & ND & \\
\hline 01-01v1621 & 2000 & Germany & Koi carp & AY424884 & ND & \\
\hline $19-0052 / 94$ & 1994 & Germany & Koi carp & AY424885 & ND & \\
\hline $19-0059 / 95$ & 1995 & Germany & Koi carp & AY424886 & ND & \\
\hline $19-0073 / 94$ & 1994 & Germany & Koi carp & AY424887 & ND & \\
\hline $17 / 00-47 / 3$ & 2000 & Germany $^{\mathrm{f}}$ & Common carp & AY424888 & ND & \\
\hline F177 & 2003 & UK & Crucian carp & EF417828 & ND & \\
\hline F183 & 2003 & UK & Koi carp & EF417829 & ND & \\
\hline F193 & 2003 & UK & Crucian carp & EF417832 & ND & \\
\hline F 223 & 2003 & UK & Koi carp & EF417830 & ND & \\
\hline G151 & 2004 & UK & Koi carp & EF417831 & ND & \\
\hline G221 & 2004 & UK & Koi carp & EF417827 & ND & \\
\hline 992 & 2003 & Tianjin, China & Common carp & ND & AY842489 (Liu et al. 2004) & Iaii \\
\hline 890 & 2003 & Tianjin, China & Koi carp & ND & -(Liu et al. 2004) & Iai \\
\hline AI & 2006 & China & Common carp & DQ097384 & DQ097384 (Teng et al. 2007) & Iaii \\
\hline A2 & 2006 & China & & DQ491000 & DQ491000 & Iaii \\
\hline 978 & 2004 & China & Common carp & ND & AY842488 (Liu et al. 2005) & Iaii \\
\hline 926 & 2004 & China & Common carp & ND & AY842487 (Liu et al. 2005) & Iai \\
\hline 772 & 2004 & China & Goldfish & ND & AY842486 (Liu et al. 2005) & Iai \\
\hline 461 & 2004 & China & Common carp & ND & AY842484 (Liu et al. 2005) & Iai \\
\hline 464 & 2004 & China & Koi carp & ND & AY842485 (Liu et al. 2005) & Iai \\
\hline
\end{tabular}


Table 2. Oligonucleotide primer sets used to amplify and sequence the SVCV P genes, showing the relative position of the primers based on the published sequence for SVCV genome (Hoffman et al. 2002; AJ318079)

\begin{tabular}{|lll|}
\hline Oligonucleotide & Sequence & Location \\
\hline SVCVPAF & CTGATGTCTCTACATTCG & $1407-1422$ \\
SVCVPAR & CTGCTACAACCTATATTTTTG & $2336-2318$ \\
SVCVPF & GTGATGTCTCTACACTC & $1407-1421$ \\
SVCVPR & GCGCTATAACCTGTATTTTTG & $2336-2318$ \\
MD7 & ATATTTTCTTCATCATCAACTATC & $1360-1383$ \\
MD8 & CACCGAGGCCGTTATAGCG & $1818-1800$ \\
MD9 & ACGGCAGACACAGTTTGGTAC & $1762-1782$ \\
MD10 & AATCTCGAATGGTCAGGCTTAG & $2210-2190$ \\
MD11 & AACTAGGGACCTTTCTTCTAC & $2161-2181$ \\
MD12 & AACTCCCTTGCACCTTGTTAG & $2730-2710$ \\
\hline
\end{tabular}

was verified by restriction digestion using ECORI.

Sequencing analysis. M13 primers (forward and reverse) were used for sequencing clones. At least 2 clones, one from each of the independent amplifications, were used to construct nucleotide consensus sequences. The primers used in the initial amplification were used for direct sequencing reactions of $\mathrm{P}$ and G-gene products. Cycle sequencing was performed using the Applied Biosystems 3130/ 3131x/ Genetic Analyzers, Big Dye Terminator V1.1 Cycle Sequencing Kit. Editing and assembly of sequence trace (ABI) files and alignments of contigs were performed

in each PCR tube. The reactions were conducted in a GeneAmp PCR System 9600 thermocycler programmed to conduct a single cycle of reverse transcription at $50^{\circ} \mathrm{C}$ for $30 \mathrm{~min}$, followed by 35 cycles of denaturing at $95^{\circ} \mathrm{C}$ for $1 \mathrm{~min}$, annealing at $50^{\circ} \mathrm{C}$ for $1 \mathrm{~min}$, elongation at $72^{\circ} \mathrm{C}$ for $1 \mathrm{~min}$, and a single final elongation at $72^{\circ} \mathrm{C}$ for $10 \mathrm{~min}$. PCR products were either purified using the QIAquick Spin PCR Purification Kit according to protocol for direct nucleotide sequencing (Qiagen), or inserted into an appropriate cloning vector. PCR products of $930 \mathrm{bp}$ were checked by $1 \%$ agarose gel electrophoresis with a $1 \mathrm{~kb}$ DNA ladder (Promega) with positive and negative controls. Alternatively, the complete $\mathrm{P}$ gene and flanking sequences were amplified as 3 overlapping fragments using primer sets MD7/MD8, MD9/MD10 and MD11/ MD12 (Table 2). Again, the amplifications were performed in duplicate to avoid errors introduced by the Taq polymerase, and the products were prepared for direct sequencing using the Freeze and Squeeze Kit (BioRad) following the manufacturer's instructions. The G gene sequences products were generated using Primers SVCV R2 and SVCV F1 using the method of Stone et al. (2003).

TA cloning. The PCR products of the $\mathrm{P}$ gene from the 5 US isolates (PBO4-1664, PB02-131, PBO2-46, 266921, 04-5061) and 4 non-US isolates (G108,G067,G083, H243) mentioned previously were cloned into vector pCR2. $1^{\circledR}$ using the TOPO TA Cloning kit according to manufacturer's protocol (Invitrogen). The US isolates and the most recent non-US isolates were cloned for further studies e.g. gene expression and vaccine development.

Positive recombinant plasmids were purified and isolated using the Promega Plus SV Mini-preps DNA Purification System according to protocol, except that $50 \mu \mathrm{l}$ of nuclease-free water was used for the final elution instead of the recommended $100 \mu \mathrm{l}$. The presence of a $1 \mathrm{~kb}$ insert and $3.9 \mathrm{~kb}$ vector in purified plasmids using either the VectorNTI software or Sequencher program from Gene Codes Corporation.

Phylogenetic analysis. Nucleotide sequence alignments were performed by AlignX contained within the VectorNTI software package or Clustal X program version1.83 (Thompson et al. 1997). Pairwise and multiple alignment gap opening and gap extension settings were 15.00 and 6.66, respectively. Since PCR primers used to amplify the complete $\mathrm{P}$ gene anneal with the first 15 (Asian) or 14 (European) nucleotides and the last 17 nucleotides (both Asian and European) and may not reflect virus-strain specific nucleotide variation in this region, we excluded these nucleotides from our phylogenetic analysis. Phylogenetic analyses were performed using Paup*4.0 (Swofford 2000) and MEGA version 3.1 (Kumar et al. 2004). Phylogenetic trees were generated by the NeighborJoining (NJ) method (Saitou \& Nei 1987) on uncorrected p-distances or corrected under a general time reversible model of nucleotide substitution with site rate variation estimated using the discrete-gamma correction (0.4663) with 4 rate categories $(\mathrm{GTR}+\mathrm{G})$, empirical base frequencies, and without a term for proportion of invariable sites (Gu et al. 1995, Swofford et al. 1996). The GTR+G model was identified by likelihood ratio test and the Akaike Information Criterion as the best-fit to the data using MrModeltest 2.2 (Nylander 2004) in conjunction with PAUP*4.0. Three phylogenetic analyses were conducted to (1) perform an independent comparative analysis between 11 SVCV P genes (930 bp Asian and 930 bp European region) and 14 SVCV G genes (426 bp region) to confirm the P gene's ability to detect Genogroups Ia to Id, (2) assess the genetic diversity of the P gene to discriminate among 34 SVCV Genogroups Ia, Ic and Id sequences, and (3) determine the genetic relationships between 35 SVCV Genogroup Ia isolates based on the nucleotide sequence of the $\mathrm{P}$ gene and $\mathrm{G}$ gene sequences. 
Nonparametric bootstrapping was performed to assess node support with a minimum of 1000 and maximum of 2000 re-samplings from the original data set to confirm 95\% reproducibility in the resulting trees (Hall \& Barlow 2006). Tree diagrams were displayed using TreeView win32 software (Page 1996).

\section{RESULTS}

\section{PCR primer pairs distinguish Asian, European and Russian SVCV strains}

To analyze the genetic diversity among SVCV isolates, an initial total of 59 (54 SVCV; 1 Piry, 1 PFRV and 3 TenRV) rhabdoviruses from 12 countries during the pe- riod 1969 to 2006 were tested (Table 1). The oligonucelotide primer pairs designed in this study specifically amplified the entire $\mathrm{P}$ gene coding region (codon 1 ATG - codon 930 TAG) (data not shown). Detection of the amplified (930 bp) PCR products of the P gene of US isolates was visualized by agarose gel electrophoresis.

It was possible to amplify the P gene from all SVCV isolates using either the Asian or European primer pairs. The SVCV isolates in Genogroup Ia (18 out of 34) were amplified by the Asian primers (SVCPAF/SVCPAR), while 16 SVCV isolates (Genogroups Ic and Id) were amplified by the European primers (SVCVPF/SVCVPR), (data not shown). Neither Asian nor European primer pairs were able to amplify the P gene from PFRV isolate F4 (Genogroup III), or from TenRV isolates 9946631.1,

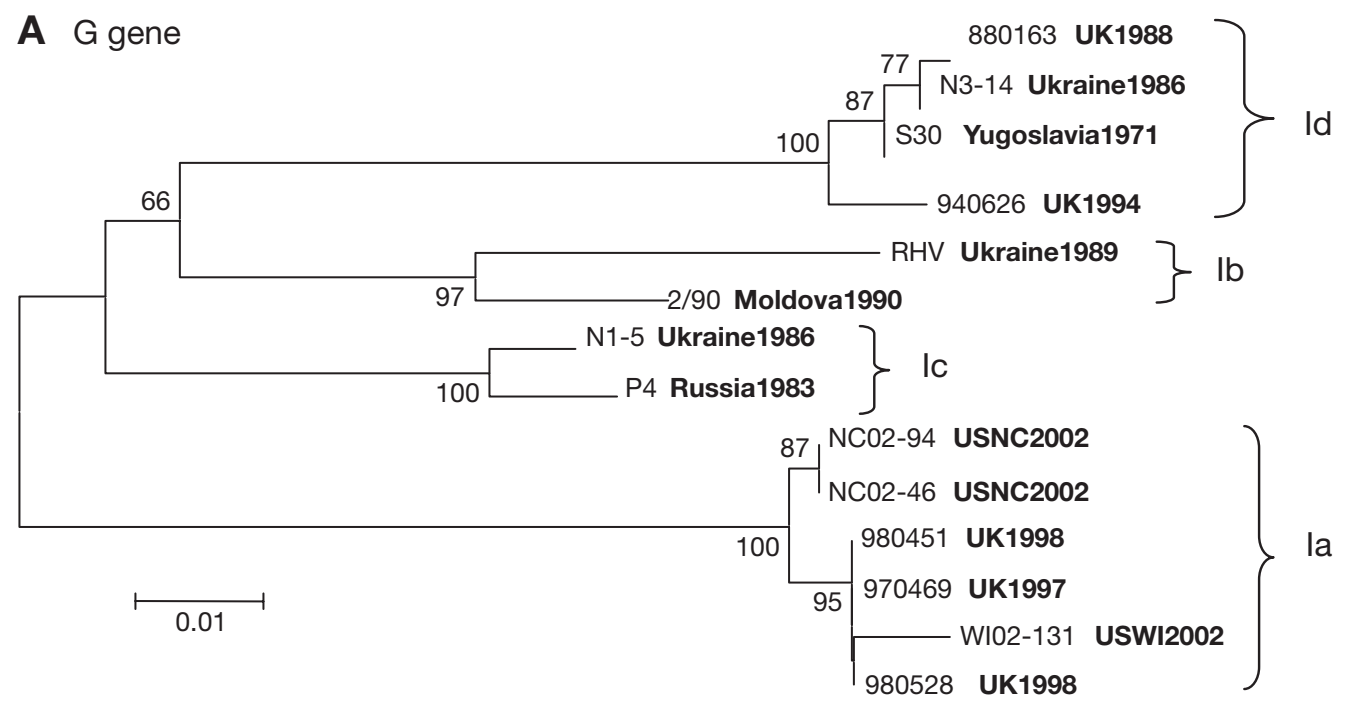

B P gene

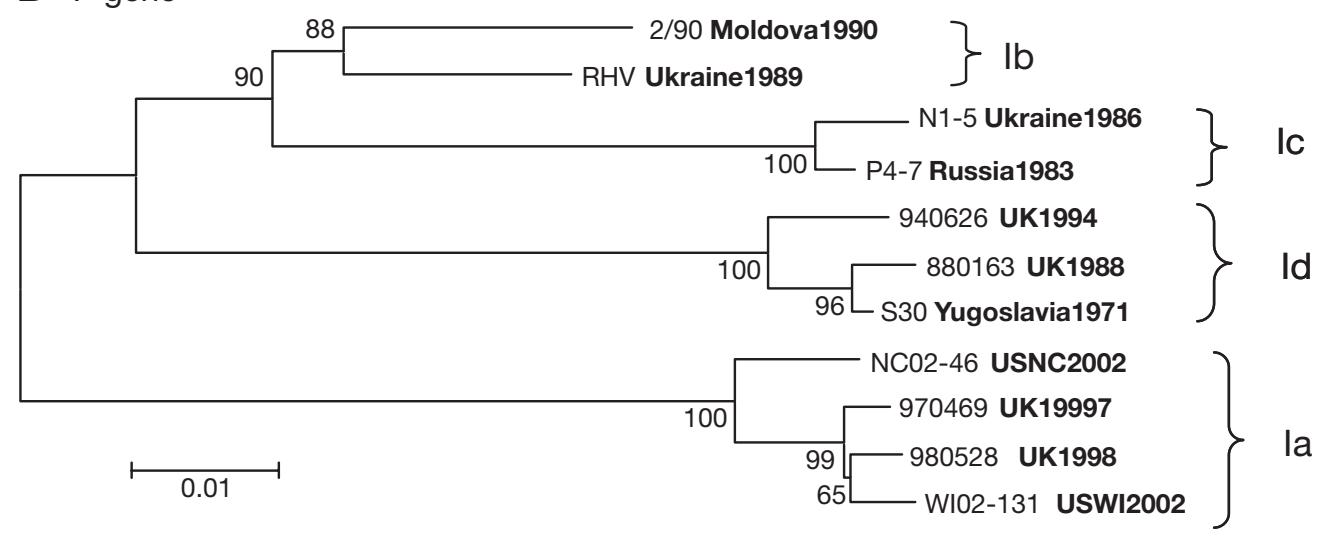

Fig. 1. Phylogenetic trees generated by neighbor-joining analyses of (A) a 426 bp partial glycoprotein gene sequence and (B) the $898 \mathrm{bp}$ phosphoprotein gene sequence of Genogroup Ia to Id SVC virus isolates. The P gene sequences were generated in present study. The G gene sequences for isolates 940626 and 88163 were generated in the present study; all other G gene sequences were published previously by Stone et al. (2003). Analyses were done on 1000 bootstrapped data sets and values of $>70$ are shown on the trees. See Table 1 for details of isolates 
950237 and 84-4 (Genogroup IV). The Asian primer pair did not amplify the European P genes, nor did the European primer pair amplify the Asian $\mathrm{P}$ genes (data not shown).

\section{Comparison of $P$ and $G$ gene sequences reveals similar topologies among same virus strains}

Twenty-nine complete SVCV P genes and 15 partial G genes were deposited into GenBank database under accession numbers DQ904366-DQ904370, DQ9106041， DQ916043-DQ916044， DQ916047-DQ 916056, EF216718, EF417826-EF417832, AM50152426, AM501510-23, and AM501527, respectively (Table 1).

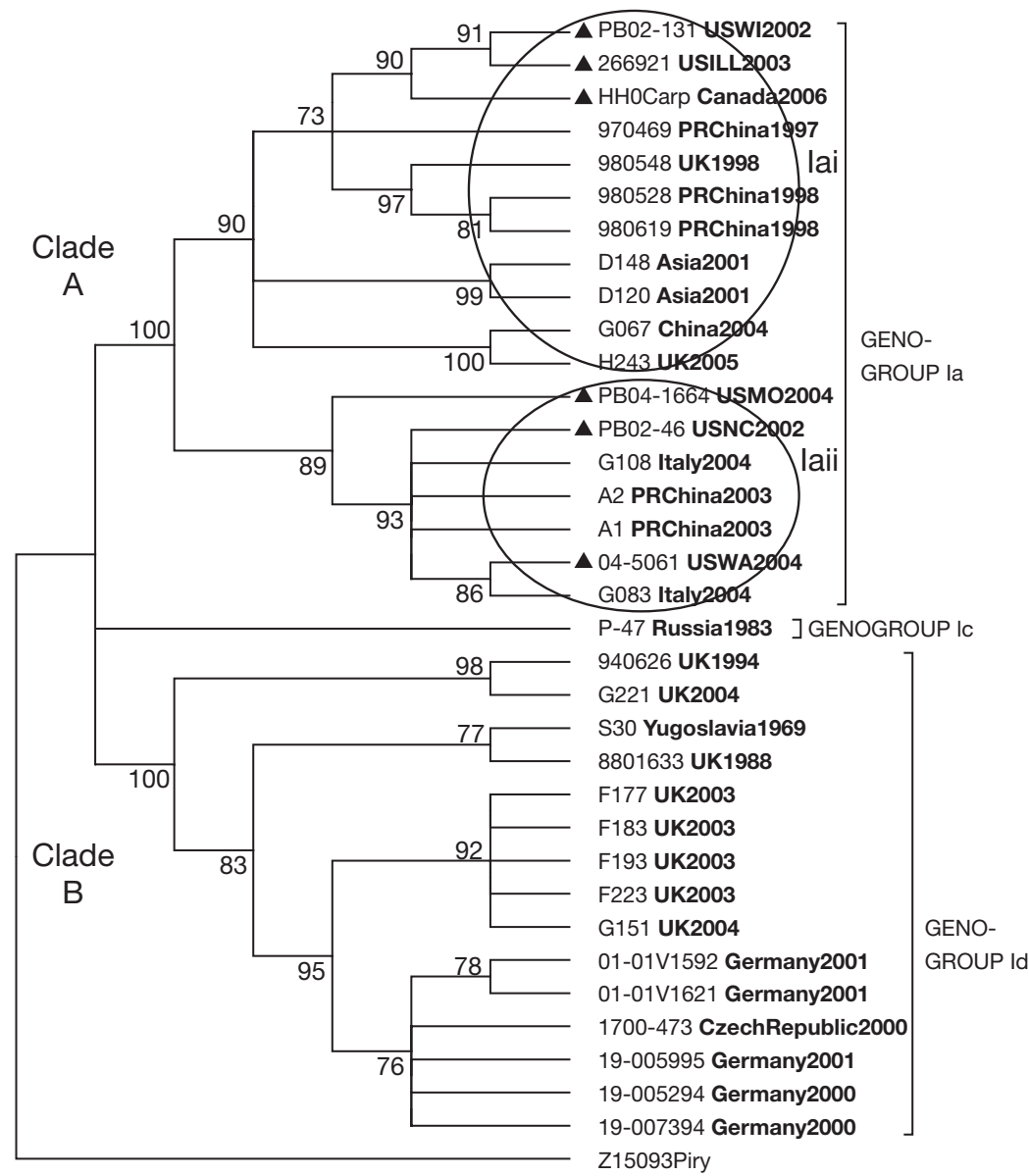

Fig. 2. Condensed tree generated by neighbor-joining analyses of the 898 bp phosphoprotein (P) gene sequence of Genogroup Ia, Ic and Id SVC virus isolates showing topology only; distinct Subgroups Iai and Iaii are circled. Bootstrap percentages are displayed beside the corresponding nodes and are based upon 2000 resamplings with values of $\geq 70$ shown on the tree. (Piry virus rooted as outgroup.) All P genes were generated except for A1,A2, 01-01v1592,01-01V1621,AY424888, 190052995,19-005294,19-00739. A: North American SVCV isolates. See Table 1 for details of isolates
We were interested in determining whether $\mathrm{P}$ gene sequences displayed relationships among SVCV strains similar to those that have been previously demonstrated by analyses of G gene sequences. Neighbor-joining analysis based on the $\mathrm{P}$ gene sequence produced a similar tree showing reciprocal monophyly for gene lineages and highly similar phylogenetic topologies to those described previously for the G gene (Stone et al. 2003, Dikkeboom et al. 2004, Warg et al. 2007). There were 4 distinct genogroups of SVCV (Ia to Id) with the US isolates clustering in the Ia group together with the viruses isolated in the UK from ornamental imports from China (Fig. 1). The isolates RHV and 2/90 clustered together (Genogroup Ib) as did N1-5 and P4 (Genogroup Ic). The SVCV reference strain (S30) was assigned to Genogroup Id. Separation into the 4 genogroups based on the $\mathrm{G}$ gene sequences was supported by bootstrap values of $\geq 97 \%$.

\section{Phylogenetic analysis of SVCV strains reveals 2 clades, 3 genogroups and 2 subgroups}

The NJ phylogram including $\mathrm{P}$ gene sequences of 29 non-US and 5 American SVCV isolates identified 2 major clades, 3 genogroups and 2 subgroups in Fig. 2. Bootstrap values of $100 \%$ indicate strong support for the distinct clades (A and B). Each clade corresponds to a specific geographical region in Asia (clade A) or Europe (clade B). In keeping with the genogroup identification of Stone et al. 2003, the clades clustered in their designation of Genogroup I, Subgenogroups Ia, Ic and Id for SVCV. The ranges of percent identity within Genogroups Ia and Id were 100 to $97.5 \%$, and 100 to $88.1 \%$, respectively.

Two subgroups (Iai and Iaii) with high support values (90 and $89 \%$ ) of Asian and American SVCV isolates were contained in Genogroup Ia, and there were 2 subgroups with high bootstrap values (100 to $83 \%$ ) in Genogroup Id of SVCV nucleotide sequences from Germany, Czech Republic, UK, and Yugoslavia (Fig. 2). However the subgroups in Id formed only one cluster with $76 \%$ bootstrap support using the GTR+G model (data not shown). Focusing within the Asian clade, Italy import (G083) shared 100\% nucleotide identity with WA isolate (04-5061) and clustered with the China isolates (A1 DQ097384, 98.8\%, A2 DQ491000, 99.6\%). Italy import (G108) shared 99.5\% nucleotide identity with NC (PB02-46). UK import (970469) clustered among ILL (266921), WI (PB02-131) and 

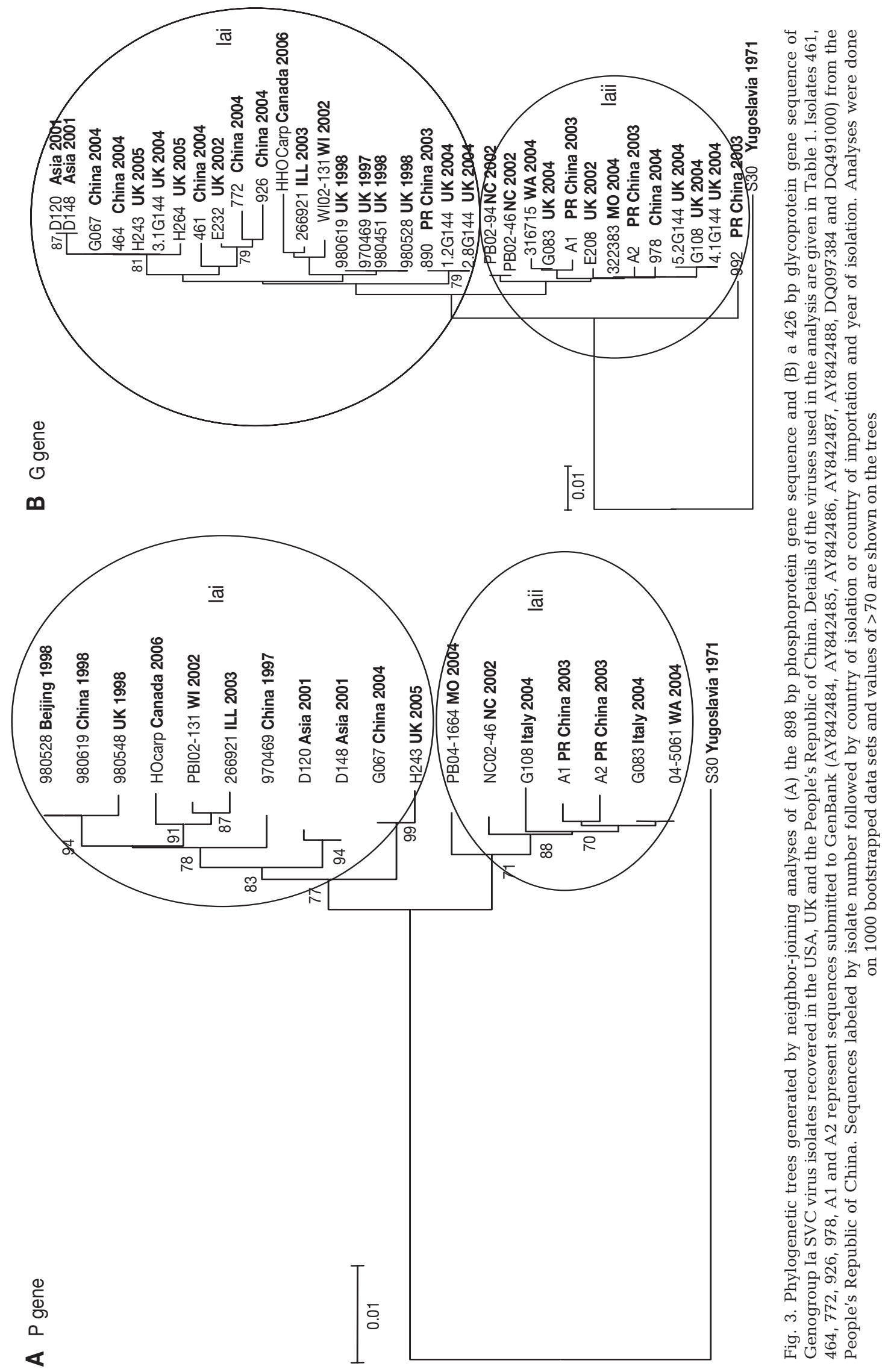
Canada (HHOCarp06) isolates sharing nucleotide identities of $99.2 \%, 99.3 \%$ and $99.2 \%$, respectively. The Canada (HHOCarp06) isolate shared nucleotide identities of $99.5 \%$ with WI (PB02-131) and 99.4\% with ILL (266921).

Bootstrap values $\geq 89 \%$ further support isolates from China (A1 and A2), and Italy imports, (G083, G108) as likely trace sources of the WA and NC outbreak strains along with isolate 970469 as a likely trace source of the WI and ILL strains (Fig. 2). Although isolate 980619 was an import from an unknown source, it clustered (sharing 100\% nucleotide identities) with an import from China (980528) and showed 99.8\% nucleotide identity with an isolate (980548) that was thought to have originated in the UK. However, the genetic analysis and additional epidemiological information suggests that the above imports may have ultimately originated from the same region of China.

\section{Expanded analysis of the Ia genogroup based on $P$ and $G$ gene sequences}

Based on our results from Fig. 2, which indicated 2 distinct subgroups in the Ia genogroup, we decided to expand our $\mathrm{P}$ and $\mathrm{G}$ gene analysis with all available Ia genogroup SVCV isolates from North America and the UK. Multiple alignment of the $898 \mathrm{bp} \mathrm{P}$ gene and 426 bp G gene sequences of the SVCV Ia virus isolates revealed a high degree of sequence divergence, with between 0 and 21 nucleotide substitutions (97.75 to $100 \%$ nucleotide identity) and 0 to 11 nucleotide substitutions (95.5 to $100 \%$ nucleotide identity) in the $\mathrm{P}$ and $\mathrm{G}$ genes, respectively.

Phylogenetic analysis based on the P gene suggested a further division within the SVCV Ia clade (Iai and Iaii) supported by bootstrap values of $>72 \%$ (Fig. 3A). Analysis based on a more comprehensive data set from the $\mathrm{G}$ gene revealed a number of discrete clusters of virus sequences, with clustering of isolates that was consistent with the P gene analysis; but in many cases the divisions within the SVCV Ia clade of the G gene were not supported by bootstrap analysis (Fig. 3B).

Based on the G gene sequence, strong support (81\%) was provided by bootstrap analysis for the clustering of isolates D120 and D148 from 2001 with isolates from 2004 (G067 and G144 3.1), 2005 (H243 and H264) and sequence data for an isolate purported to have come from China (isolate 464 [AY842485]). There was also good support (79\%) for a genetic link between E232, a UK isolate from 2002 and the sequence data for isolates 772 and 926 from China, and also for a link (79\%) between 2 UK isolates (G144 1.2 and 2.8) from 2004 and the Chinese isolate 890. In the latter case, the 3 viruses shared identical nucleotide sequences.
The analysis of the $\mathrm{P}$ gene provided good support $(71 \%)$ for Subgroup Iaii cluster, (unlike the similarly observed cluster using the $\mathrm{G}$ gene sequence) placing the isolates from NC (NC02-46), MO (PB04-1664) and WA (04-5061) with the UK isolates from 2004 (G083 and G108) and further data for virus isolates from China (A1 DQ097384, A2 DQ491000). In addition, there was good support (77\%) for (Subgroup Iai) clustering of the virus isolates from WI (WI02-131), ILL (266921) and the UK isolates from 1997 and 1998 (970469, 980528 1.1, 980548 and 980619) with strong support of $91 \%$ within Canada, WI and ILL. However, the $\mathrm{G}$ gene bootstrap values did not support the distinction of Subgroup Iai.

It appears from epidemiological data that these sequences also clustered according to geographic location and fish species from which the virus was isolated. Isolates from WI, ILL and Canada were taken from feral common carp, while isolates from $\mathrm{MO}, \mathrm{NC}$, and WA were from commercially farmed koi carp and goldfish. This species difference was not noted in Stone et al. 2003 and Hoffman et al. 2005. Imported breeder production stocks appear to have SVCV strains in Subgroup Iaii different from those in certain feral carp in Subgroup Iai in the USA.

\section{DISCUSSION}

This is the first epidemiological study to examine the diversity of SVCV nucleotide sequences of the phosphoprotein gene in comparison with the glycoprotein gene. Our studies examined 43 (35 Ia and $8 \mathrm{Ib}$ to Id) isolates from different geographic regions worldwide. Our results indicate that previous SVCV taxonomic groupings (Genogroups Ia, Ib, Ic and Id) identified with $\mathrm{G}$ gene sequences are also identifiable using $\mathrm{P}$ gene sequences. Phylogenetic analysis of the $\mathrm{P}$ gene sequences revealed 2 distinct clades (A and B), 4 genogroups (Ia, Ib, Ic and Id) and 2 subgroups (Iai and Iaii). Both $\mathrm{P}$ and $\mathrm{G}$ gene sequence analysis of genogroup Ia demonstrated distinct subgroups (Iai and Iaii) within Group Ia. However, the P gene had greater resolution and was supported by greater bootstrap support values. In the USA and Canada, all 6 homologous SVCV isolates belong to Genogroup Ia, confirming the $\mathrm{G}$ gene phylogenetic analysis of Warg et al. 2007. In addition, they are now designated into Subgroups Iai and Iaii (Table 1). This offers the potential for novel and additional information in phylogenetic analyses of SVCV molecular epidemiology.

Over the last decade, the majority of reported isolations of SVCV have been of the Ia genotype. Although there is good documentation to support the origins of UK isolates from 1998, some of the remaining group Ia 
viruses were isolated from fish held on sites that import fish from a number of countries, including China, and there are no data to support a direct link between the virus and the fish of Chinese origin. As part of an ongoing epidemiological investigation, our current study aimed to establish the genetic relationship between the group Ia SVCV isolates from North America and UK and those viruses isolated in China.

The phylogenetic data suggest that the occurrences of group Ia SVCV in the USA and the UK are likely to have arisen following multiple independent introductions of the virus. The data (1) provide evidence of a genetic link between the SVCV isolates from the UK and one of the 2 recognized isolates from China (Liu et al. 2004), (2) establish genetic links between the 1998 isolates from the UK and isolations made in the USA and Canada, and (3) establish a link between USA and UK isolates and the published sequence data for SVC viruses isolates in China (Liu et al. 2004, 2005, Teng et al. 2007).

Phylogenetic analysis of US isolates based on the P gene identified 2 main subgroups (Iai and Iaii), which support at least 2 independent introductions of SVCV. The viruses from Wisconsin in 2002 (PB02-131), Illinois in 2003 (266921) and the more recent outbreak in Canada in 2006 (HHOcarp06) clustered with the UK isolates from 1998 in Subgroup Iai. From the data it can be inferred that all 3 isolates in North America and the UK isolates share a common ancestor, and since the UK isolates were recovered from fish intercepted at the point of entry into the UK from Beijing, it is most likely that the common ancestor originated from a related source in China. It remains unclear, however, whether the viruses isolated in North America were introduced directly from China or entered the country via a third party.

The North Carolina (PB02-46), Missouri (PB02-1664) and Washington isolates (04-5061) were assigned to Subgroup Iaii together with UK isolates from 2004. Indeed, based on the $100 \%$ nucleotide identity to a 2004 UK import from Italy (isolate G083), the data suggest that the 2004 Washington isolate (04-5061) represents a third introduction into the USA from a common source rather than a reemergence from the 2002 NC isolate (PB02-46). More significantly, 2 sequences for 2 Chinese viruses (A1 and A2; DQ097384 and DQ491000) isolated in 2006 cluster within this subgroup. Two UK isolates from goldfish imported into the UK via an Italian supplier in 2004 were also assigned to the same group. Similar relationships were obtained from analysis of the $\mathrm{G}$ gene sequence data, but in contrast to the $\mathrm{P}$ gene sequence data the clusters were not supported by the bootstrap analysis.

Based on the G gene data, 2 of the UK isolates (G144 1.2 and 2.8) from goldfish from 2004 shared 100\% nucleotide identity with 890, a virus isolated from koi carp in Tianjin, China in 2003 (Liu et al. 2004). This finding is surprising, given that the infected farm site in China ceased exporting fish after the isolation of SVCV in 2003. Since the goldfish were part of a stock of fish imported into the UK from a supplier in Italy we can only assume that the virus was introduced into the Italian suppliers holding facility prior to the discovery of SVCV in Tianjin in 2003. Alternatively, the Italian supplier may have received fish from sources that had contact with the carp culture sites in Tianjin prior to the discovery of SVCV, and the infection has remained undetected on these contact sites.

One hundred percent nucleotide identity was shared between G067 isolated from goldfish imported from China in 2004 and G144 3.1 from koi carp imported into the UK from Italy in the same year, H243 which was isolated from common carp in the UK in 2005, and the G gene sequence of isolate 464 (AY842485) recovered from koi carp in China. The latter sequence was submitted to GenBank in 2004, suggesting that the virus was identified between the first discovery of SVCV in June 2003 and the sequence submission date of December 2004. This date is consistent with the exportation of infected fish to the UK and Italy during 2004, and the timing also allows for the transfer of infected fish to the UK from Italy in the same year. At present, there is no documentation to link the common carp in this case with a fish import.

During the period from 1997 to 2006, there were 32 separate isolations of SVCV in the UK, USA and Canada. Sequence analysis has revealed strong genetic relationships between 14 of the 26 viruses isolated in the UK during this period, and viruses with origins in China. In some cases, the nucleotide sequences were identical, suggesting a direct link between the infected fish. In at least one case where the fish were sampled during routine import checks, the infection can be traced to China, but in other cases, particularly where fish movement records show that fish from more than one country were held on the same site, it is more difficult to establish a direct link to the Chinese ornamental fish industry. The isolation of the group Ia virus from fish imported from Italy complicates matters further, and additional investigations are required to establish whether the Italian suppliers were acting as a holding facility for fish destined for the European market. Nonetheless, the sequence divergence supports the introduction of the virus into the UK and the USA on a number of separate occasions from common ancestral sources.

Histological samples from a wild common carp kill in the Pentenwell Flowage Wisconsin River, USA in 1989, produced RT-PCR products that indicated the presence of an SVCV virus of European genotype 
(Subgenogroup Id) (R. M. Le Deuff, S. Marcquesnski, P. F. Dixon unpubl. data). Johnson et al. (1999) also reported on a European genotype SVCV from penaeid shrimp in Hawaii. This demonstrates that different strains (besides genotype Ia) of SVCV exist in the US, suggesting further independent introductions of this virus.

Biosecurity plays a very important role in prevention and spread of disease. Knowledge of likely geographical disease-risk sources coupled with health certifications demonstrating freedom of disease from SVCV risk areas would be important in preventing new SVCV introductions.

The US Department of Agriculture APHIS has so far been unable to recover SVCV from their volunteer SVCV-susceptible broodstock surveillance survey which covers 30 states and was initiated in 2002 (O. Miller unpubl. data). However, if there were evidence of endemic SVCV in North America it would most likely be significantly distinct from European and Asian isolates, and indemnification and depopulation policies would need to be revised.

The UK regulates the importation of fish, and the only hosts of SVCV that can be legally imported are ornamental fish such as goldfish, koi carp etc. There has been SVCV surveillance in the UK since the first major outbreak in 1988. There is evidence that some of the isolations resulted from the illegal importation of fish.

Currently, the majority of international trade of SVCV-susceptible fish consists of imports into the European Union and the USA. Asia represents >90\% of the world aquaculture production (Bondad-Reantaso et al. 2005). Identifying trace country of origin from point source outbreaks could avert further introductions and spread of SVCV. Thus, the recent USDA APHIS implementation in the autumn of 2006 of SVC import protocols, as other countries require, could bring some degree of balance to introductions of transboundary diseases (Federal Register 2006).

The recent expansion of the European Community to include several eastern European countries, in which carp culture is a significant part of the aquaculture industry, could see a significant shift in the carp trading patterns, particularly, imports of coldwater cyprinid species such as koi carp and grass carp into the UK.

Phylogenetic analysis with bootstrapping is an additional tool that epidemiologists can use for making inferences about likely trace sources of outbreak strains. The coding region of the $\mathrm{P}$ gene (930 bp) of SVCV used in this study was well suited for molecular epidemiological studies to determine nucleotide similarities among outbreak strains and genetic relatedness between American and non-American isolates of
SVCV. Combining the results of the P-gene analysis with G-gene sequences could prove an invaluable tool in the surveillance and control of SVCV as the international trade in SVCV-susceptible fish increases in the future.

Acknowledgements. We sincerely thank A. Goodwin, K. Snekvik, J. Thompson, J. Warg, and B. Souter for providing us with the SVCV isolates. The authors are also most grateful to G. Kurath, Western Fishery Research Center, Seattle, J. Thorne, R. Anholt and B. Wiegmann of North Carolina State University for their assistance in the preparation of this manuscript. This study was funded by USDA Grant no. 52533.

Note added in proof. On June 28, 2007, SVCV was also confirmed in the upper Mississippi river between Onalaska (Wisconsin) and Dresbach (Minnesota) from feral common carp samples submitted by the US Fish and Wildlife Service who were investigating a carp kill that occured on May 7 , 2007 (www.fws.gov/midwest/news/release07-68.html)

\section{LITERATURE CITED}

Ahne W, Bjorklund HV, Essbauer S, Fijan N, Kurath G, Winton JR (2002) Spring viremia of carp. Dis Aquat Org 52:261-272

Banerjee AK (1987) Transcription and replication of rhabdoviruses. Microbiol Rev 51:66-87

Bjorklund HV, Higman KH, Kurath G (1996) The glycoprotein genes and gene junctions of the fish rhabdoviruses spring viremia of carp virus and hirame rhabdovirus: analysis of relationships with other rhabdoviruses. Virus Res 42: $65-80$

Bondad-Reantaso MG, Subasinghe RP, Arthur JR, Ogawa K, Chinabut S, Adlard R, Tan Z, Shariff M (2005) Disease and health management in Asian aquaculture. Vet Parasitol 132:249-272

Dikkeboom A, Radi C, Toohey-Kurth K, Marcquenski S and 5 others (2004) First report of spring viremia of carp virus in wild common carp in North America. J Aquat Anim Health 16:169-178

Emerson SU, Yu Y (1975) Both NS and L proteins are required for in vitro RNA synthesis by vesicular stomatitis virus. J Virol 15:1348-1356

Federal Register (2006) Rules and regulations, 9 CFR Part 93 71:51429-51437 available at: http://frwebgate.access. gpo.gov/cgi-bin/getpage.cgi?dbname=2006_register\& position=all\&page $=51429$

Fijan N (1999) Spring viremia of carp and other viral diseases and agents of warmwater fish. In: Woo PTK (ed) Fish diseases and disorders, Vol 3. CAB International, London, p $177-244$

Fijan N, Petrinec Z, Sulimanovic D, Zwillenberg LO (1971) Isolation of the viral causative agent from the acute form of infectious dropsy of carp. Veterinarski Archiv 41:125-138

Goodwin A (2002) First report of spring viremia of carp virus in North America. J Aquat Anim Health 4:161-164

Gu X, Fu YX, Li WH (1995). Maximum likelihood estimation of the heterogeneity of substitution rate among nucleotide sites. Mol Biol Evol 12:546-557

Hall BG, Barlow M (2006) Phylogenetic analysis as a tool in molecular epidemiology of infectious diseases. Ann Epidemiol 16:157-169 
Hoffmann B, Schutze H, Mettenleiter TC (2002) Determination of the complete genomic sequence and analysis of the gene products of the virus of spring viremia of carp, a fish rhabdovirus. Virus Res 84:89-100

Hoffmann B, Beer M, Schutze H, Mettenleiter TC (2005) Fish rhabdoviruses: molecular epidemiology and evolution. Curr Top Microbiol Immunol 292:81-117

Johansson T, Nylund S, Olesen NJ, Bjorklund H (2001) Molecular characterisation of the nucleocapsid protein gene, glycoprotein gene and gene junctions of rhabdovirus 903/87, a novel fish pathogenic rhabdovirus. Virus Res 80:11-22

Johansson T, Osttman-Myllyoja L, Hellstrom A, Martelius S, Olesen N J, Bjorklund H (2002) A novel fish rhabdovirus from Sweden is closely related to the Finnish rhabdovirus 903/87. Virus Genes 25:127-138

Johnson MC, Maxwell JM, Loh PC, Leong JA (1999) Molecular characterization of the glycoproteins from two warm water rhabdoviruses: snakehead rhabdovirus and rhabdovirus of penaeid shrimp (RPS)/spring viremia of carp virus. Virus Res 64:95-106

Koutna M, Vesely T, Psikal I, Hulova J (2003) Identification of spring viraemia of carp virus by combined RT-PCR and nested PCR. Dis Aquat Org 55:229-235

Kumar S, Tamura K, Nei M (2004) Mega3: integrated software for molecular evolutionary genetics analysis and sequence alignment. Brief Bioinform 5:150-163

Liu H, Gao L, Shi X, Gu T, Jiang Y, Chen H (2004) Isolation of spring viraemia of carp virus from cultured koi (Cyprinus carpio koi) and common carp (Cyprinus carpio carpio) in P.R. China. Bull Eur Assoc Fish Pathol 24:194-202

Liu H, Feng F, Huang J, Shi X, Gao L, Yang J, Jiang Y (2005) Amino acid sequence of a Chinese isolate of Spring Viraemia Virus of carp and preliminary analysis of the glycoprotein gene. Virol Sin 20:647-651

Nylander JA (2004) MrModeltest v2. Program distributed by the author. Evolutionary Biology Centre, Uppsala University. Available at: www.abc.se/ nylander

Oreshkova SF, Shchelkunov IS, Tikunova NV, Shchelkunova TI, Puzyrev AT, Ilyichev AA (1999) Detection of spring viremia of carp virus isolates by hybridization with nonradioactive probes and amplification by polymerase chain reaction. Virus Res 63:3-10

Ostroff SM (1999) Emerging infectious diseases 1997-1998: the role of molecular epidemiology. Mem Inst Oswaldo Cruz 94:1-3

Page R (1996) Treeview: an application to display phylogenetic trees on personal computers. Comp Appl Biosci $12: 357-358$

Editorial responsibility: Carey Cunningham, Aberdeen, UK
Roy P (1981) Phosphoproteins of spring viremia of carp virus. Virology 112:274-281

Saitou N, Nei M (1987) The neighbor-joining method: a new method for reconstructing phylogenetic trees. Mol Biol Evol 4:406-425

Shchelkunov IS, Oreshkova SF, Popova AG, Nikolenko GN, Shchelkunova TI, Ilyichev AA (2005). Development of PCR-based techniques for routine detection and grouping of spring viremia of carp virus. In: Cipriano RC, Shchelkunov IS, Faisal M (eds) Health and diseases of aquatic organisms: bilateral perspectives. Michigan State University Press, East Lansing, p 260-284

Stone DM, Ahne W, Denham KL, Dixon PF, Liu CT, Sheppard AM, Taylor GR, Way K (2003) Nucleotide sequence analysis of the glycoprotein gene of putative spring viraemia of carp virus and pike fry rhabdovirus isolates reveals four genogroups. Dis Aquat Org 53:203-210

Strommen HK, Stone DM (1997) Detection of viral haemorrhagic septicaemia (VHS) virus in fish tissues by seminested polymerase chain reaction (PCR). In: Barnes $A$, Davidson G, Hiney M, McIntosh D (eds) Proceedings of a symposium on methodology in fish disease research. Fisheries Research Services, Aberdeen, p 203-209

Swofford DL (2000) Paup*:phylogenetic analysis using parismony ( ${ }^{*}$ and other methods), Version 4. Sinauer Associates, Sunderland, MA

Swofford DL, Olsen GJ, Waddell PJ, Hillis DM (1996) Phylogenetic inference. In: Hillis DM, Moritz C, Mable BK (eds) Molecular systematics. Sinauer Associates, Sunderland, MA, p 407-514

Teng Y, Liu H, Lv JQ, Fan WH, Zhang QY, Qin QW (2007) Characterization of the complete genome sequence of the spring viremia of carp virus isolated from common carp (Cyprinus carpio) in China. Arch Virol (in press). Available at: www.springerlink.com/content/t76114qr872 t7066

Thompson J, Gibson T, Plewniak F, Jeanmougin F, Higgs D (1997) The clustalX windows interface: flexible strategies for multiple sequence alignment aided by quality analysis tools. Nucleic Acids Res 25:4876-4882

Warg J, Dikkeboom AL, Goodwin AE, Snekvik K, Whitney J (2007) Comparison of multiple genes of spring viremia of carp viruses isolated in the United States. Virus Genes (in press). Available at: www.springerlink.com/content/ j133141v872nrm58/?p=b8961663dde342ce858c6fddbcb02 8d6\&pi=1

Wolf K (1988) Fish viruses and fish viral diseases. Cornell University Press, Ithaca, NY

Zhang Q (2002) A review of viral diseases of aquatic animals in China. Acta Hydrobiol Sin 26:89-101

Submitted: September 28, 2006; Accepted: April 18, 2007

Proofs received from author(s): June 22, 2007 